\title{
A Study of Water Permeability of Coal Ash and Slag to Assess the Possibility of Their Use as Road Pavement Layers
}

\author{
I.Yu. Lange ${ }^{1}$, Y.A. Lebedeva ${ }^{2}$ and P.V. Kotiukov ${ }^{3}$ \\ ${ }^{1}$ Assistant Lecturer, Hydrogeology and Engineering Geology Department, Saint Petersburg Mining University, Russia. \\ ${ }^{2,3}$ Associate Professors, Hydrogeology and Engineering Geology Department, Saint Petersburg Mining University, Russia.
}

${ }^{3}$ ORCID: 0000-0003-4381-8542

\begin{abstract}
This paper focuses on problem of the coal combustion waste use. The possibility of using the coal ash and slug as an additional layer of road pavement is considered. Particular attention is paid to water permeability, which along with the mechanical properties determines the possibility of their use as pavement layers. A series of laboratory studies on samples from the two ash dumps were conducted. This made it possible to determine the values of permeability coefficient for various types of waste having different densities. The research was conducted in laboratory on the equipment that allowed us to change the value of hydraulic gradient (for individual experiments). It was found that filtration begins only when the initial filtration gradients are exceeded, which is associated with the features of composition and structure of coal ash and slug. These results can be used to make a final decision on feasibility of using the coal waste as a layer of road pavement.
\end{abstract}

Key words: Man-made Deposits, Ash and Slug, Road Pavement, Water Permeability, Steady Flow Conditions, Initial Hydraulic Gradient.

\section{INTRODUCTION}

One of the main tasks solved by engineering geology is the study of soils from the standpoint of their use as building materials. In the current context, the solution of this problem is becoming increasingly important in connection with the intensive formation of man-made deposits due to the growth of urban areas, the development of mining operations and the functioning of industrial enterprises. The operation of industrial enterprises using solid coal fuel leads to the formation of a large amount of stored ash and slag. According to statistics, up to 20 million tons of wastes left after coal burning at thermal power plants are formed annually in
Russia. The total area of the territories occupied by ash dumps is about $300 \mathrm{~km}^{2}$. This circumstance causes serious socioeconomic and environmental problems and encourages the search for ways to utilize these wastes $[5,6,10,17,19]$. One promising application of coal ash and slag is road construction, in which they are used both as a local binder and aggregate of bitumen concrete mixtures or as building material for filling the subgrade [16]. The use of coal waste as additional layers of pavement (for drainage, frost protection, heat insulating) assumes their compliance with a number of requirements. Among them, the most important is the water permeability of the material.

\section{METHODS}

The study of the water permeability was carried out on the ash and slag samples taken from the two ash dumps. According to the regulatory document ODM 218.2.031-2013 adopted in Russia, the samples taken belong to the low-calcium, highlyacidic ash and slag with the significant content of unburned coal residues (over than $60 \%$ ) (Table 1).

The results of the particle size analysis of the studied samples are as follows: the deposits from the ash dump No. 1 are gravel and from the ash dump No. 2 are coarse-grained. Their typical integral particle size distribution curves are shown in Fig. 1. For each type of the ash and slag, the uniformity coefficient was determined as:

$$
C_{u}=\frac{d_{60}}{d_{10}}
$$

where $d_{60}$ and $d_{10}$ are the diameters corresponding to percents finer than 10 and $60 \%$, respectively. The results of the uniformity coefficient calculation are as follows: No. 1 is uniform $\left(C_{u}=1.7\right)$ and No. 2 is non-uniform $\left(C_{u}=6.7\right)$.

Table 1. Chemical composition of the ash and slag wastes from two ash dumps

\begin{tabular}{|c|c|c|c|c|c|c|}
\hline \multirow{2}{*}{ Sampling location } & \multicolumn{2}{|c|}{ Characteristics of the ash and slag } & \multicolumn{4}{|c|}{ Content of elements in terms of oxides, $\%$ by weight* } \\
\hline & Type & Kind & $\mathrm{CaO}+\mathrm{MgO}$ & $\mathrm{SiO}_{2}+\mathrm{Al}_{2} \mathrm{O}_{3}$ & $\mathrm{Fe}_{2} \mathrm{O}_{3}+\mathrm{FeO}+\mathrm{R}_{2} \mathrm{O}$ & $\mathrm{SO}_{3}$ \\
\hline Ash dump No. 1 & \multirow{2}{*}{ Low-calcium } & \multirow{2}{*}{ Highly-acidic } & 7.6 & 78.3 & 14.1 & \multirow[b]{2}{*}{ - } \\
\hline Ash dump No. 2 & & & 8.7 & 75.5 & 15.8 & \\
\hline
\end{tabular}

Note: * Losses during calcination of the ash and slag accounted for over than $60 \%$. 


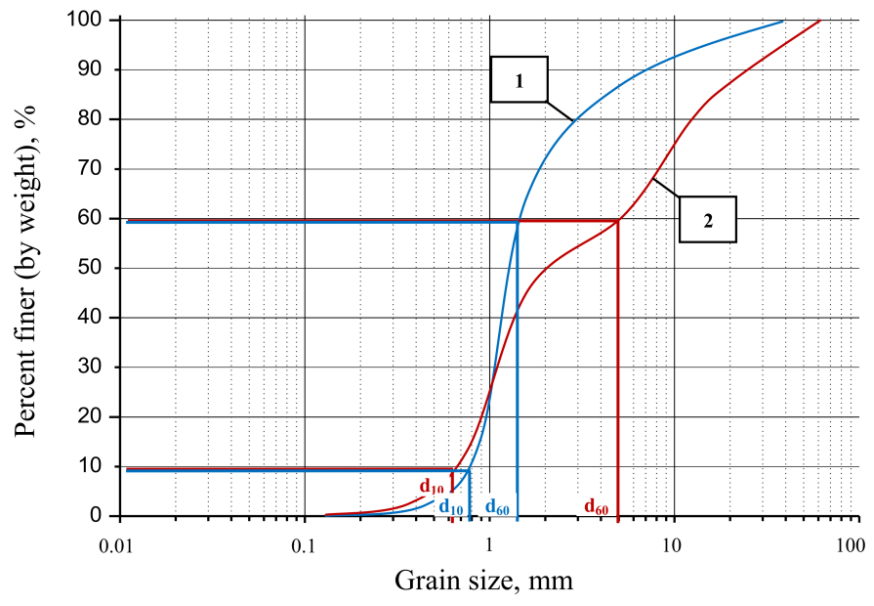

Fig. 1. Typical grain-size distribution curves in semi logarithmic scale for the ash and slag (the numbers " 1 " and

"2" indicate specimens from the relevant ash dumps)

Assessment of the water permeability of the ash and slag samples was carried out in laboratory conditions using a constant head test (steady flow conditions) [9]. This methodology is widely used in the study of sandy soils, which are similar in particle size distribution to the studied wastes. The value of the coefficient of water permeability was determined using the apparatus $C F-1$, which is the ability to conduct tests with a constant gradient in the range from 0 to 1 (Fig. 2).

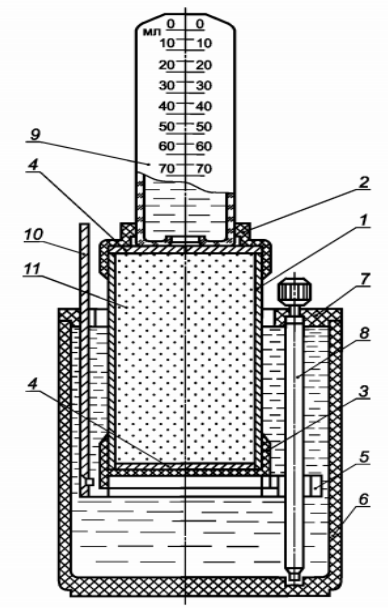

Fig. 2. Schematic view of the apparatus $C F-1$ :

1 - filtration tube; 2 - connector; 3 - perforated bottom; 4 brass net; 5 - holder; 6 - container; 7 - cover; 8 - lifting screw; 9 - measuring cylinder; 10 - hydraulic gradient scale;

$$
11 \text { - specimen [9] }
$$

To estimate the coefficient of water permeability, the specimens of the ash and slag were prepared in an extremely loose and extremely dense state (Table 2). Extremely loose state was achieved by filling the samples from a height of 5$10 \mathrm{~cm}$ without compaction. Extremely dense state was achieved by filling the filtration tube with layers of 1-2 cm thick, followed by tamping.
Table 2. Density of tested ash and slag specimens

\begin{tabular}{|c|c|c|c|}
\hline $\begin{array}{c}\text { Sampling } \\
\text { location }\end{array}$ & Density & Condition & $\begin{array}{c}\text { Average value of } \\
\text { density, } \mathrm{g} / \mathrm{cm}^{3}\end{array}$ \\
\hline Ash dump & Dense & \multirow{4}{*}{ Air dry } & 0.83 \\
\hline No.1 & Loose & & 0.69 \\
\hline Ash dump & Dense & & 0.87 \\
\hline No.2 & Loose & & 0.72 \\
\hline
\end{tabular}

Filtration tests were started only after reaching the required ash and slag density and saturating them with distilled water. The value of hydraulic gradient was progressively increased from 0.2 to 1.0 in increments of 0.2 (less often 0.1 ) from one test to another. During each experiment, the filtration time of a given volume of water was recorded.

\section{RESULTS}

It were carried out three series of tests for each hydraulic gradient value (more than 120 test in total). The results of these tests (in graphical form) are shown in Fig. 3. The graphs show the dependence of the filtration rate on the hydraulic gradient.

In the process of tests, it was found that water filtration begins only after reaching a certain hydraulic gradient, called the initial filtration gradient. Its value varied within the range of 0.49 to 0.53 . The value of the permeability coefficient was determined on the linear sections of the graphs using the well known Darcy's Law. The obtained values were reduced to conditions at a temperature of $10{ }^{\circ} \mathrm{C}$ (according to average annual groundwater temperature) using the following equation:

$$
k_{10}=\frac{\mathrm{k}}{\mathrm{T}},
$$

where $k$ and $k_{10}$ are the values of permeability coefficient at actual temperature and at temperature of $10^{\circ} \mathrm{C}$, respectively, $T$ is the temperature correction calculated as:

$$
T=\left(0,7+0,03 T_{f}\right)
$$

where $T_{f}$ is the actual water temperature during the test, ${ }^{0} C$.

The results of determining the permeability coefficients of the studied samples are shown in Table 3.

\begin{tabular}{|c|c|c|c|}
\hline \multirow[b]{2}{*}{$\begin{array}{l}\text { Sampling } \\
\text { location }\end{array}$} & \multirow[b]{2}{*}{$\begin{array}{c}\text { Density, } \\
\text { g/cm }\end{array}$} & \multicolumn{2}{|c|}{$\begin{array}{c}\text { Coefficient of water permeability } \\
\text { m/day }\end{array}$} \\
\hline & & $\begin{array}{c}\text { At actual } \\
\text { temperature of } \\
18^{\circ} \mathrm{C}\end{array}$ & $\begin{array}{c}\text { Using } \\
\text { temperature } \\
\text { correction } \\
\left(T=1^{\circ} \mathrm{C}\right)\end{array}$ \\
\hline \multirow{2}{*}{$\begin{array}{l}\text { Ash dump } \\
\text { No. } 1\end{array}$} & 0.83 & 1.4 & 1.1 \\
\hline & 0.69 & 1.5 & 1.2 \\
\hline \multirow{2}{*}{$\begin{array}{l}\text { Ash dump } \\
\text { No. } 2\end{array}$} & 0.87 & 1.3 & 1.0 \\
\hline & 0.72 & 1.4 & 1.1 \\
\hline
\end{tabular}

Table 3. Values of the water permeability coefficient of tested ash and slag wastes 


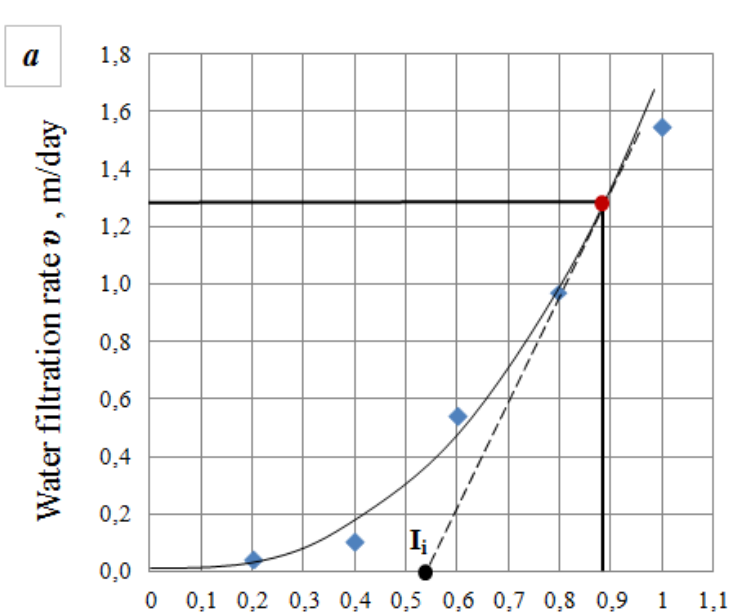

Hydraulic gradient $\boldsymbol{I}$

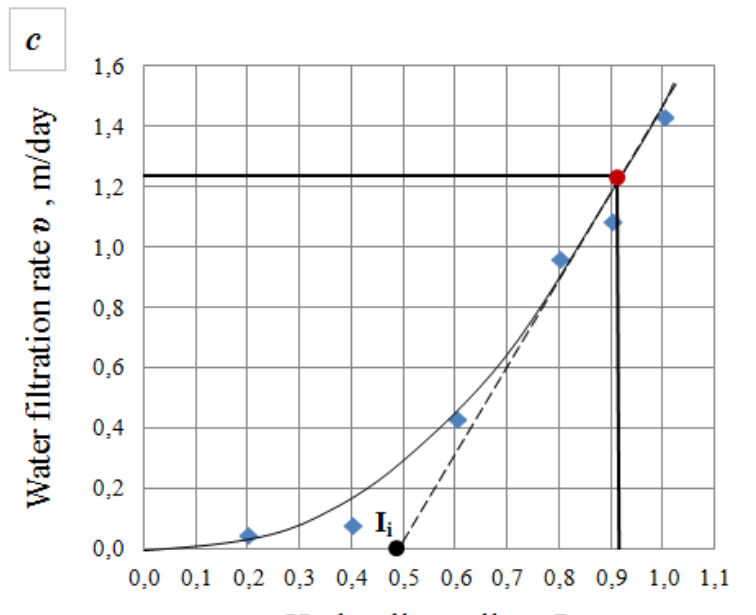

Hydraulic gradient $\boldsymbol{I}$

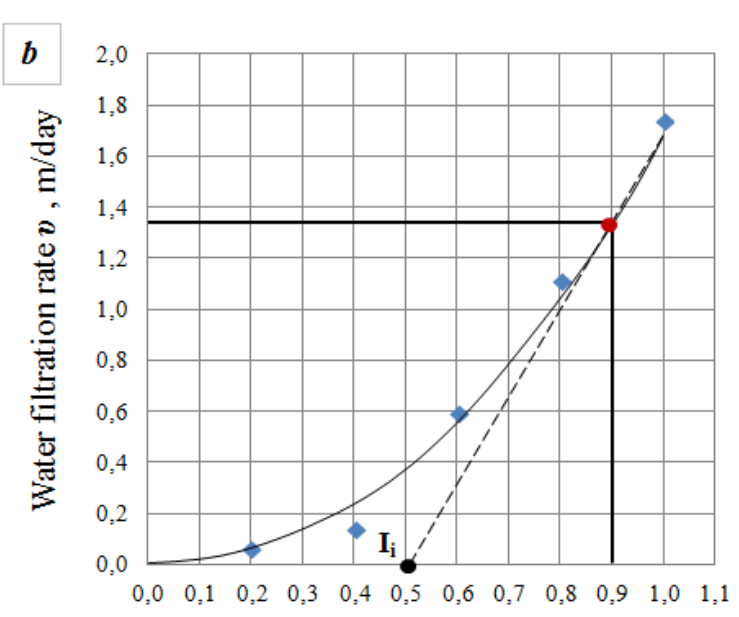

Hydraulic gradient $\boldsymbol{I}$

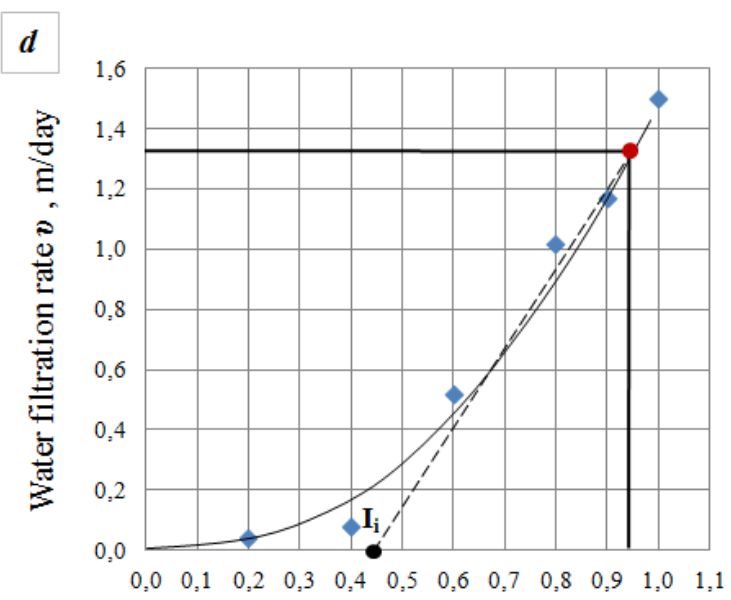

Hydraulic gradient $\boldsymbol{I}$

Fig. 3. Change in the water filtration rate $(\mathrm{m} / \mathrm{s})$ with increasing the hydraulic gradient: " $a$ " and " $b$ " represent the samples from the ash dump No. 1 in extremely dense and loose state, respectively; " $c$ " and " $d$ " represent the samples from the ash dump No.2 in extremely dense and loose state, respectively. The point selected for calculating the average value of permeability coefficient is highlighted in red

\section{DISCUSSION}

According to published data, the permeability coefficient of ash and slag wastes usually varies from 0.08 to $4 \mathrm{~m}$ /day $[4,12]$. As our test results showed, the permeability coefficients of the studied samples correspond to the above values and vary from 1.0 to $1.2 \mathrm{~m} /$ day (at $10^{\circ} \mathrm{C}$ ). At the same time, it should be noted that the studied samples, considered as coarse-grained and gravelly deposits, are often characterized by higher coefficients of water permeability exceeding $10 \mathrm{~m} /$ day [8]. In addition, filtering through them begins only when a sufficiently high initial hydraulic gradient (from 0.49 to 0.53 ) is exceeded, which is typical for finegrained wastes but not for more coarse deposits.

Such a discrepancy in the particle size and the values of the permeability coefficient is most likely due to the chemical composition of the studied samples. As noted earlier, the solid ash and slag residue is mainly represented by unburned coal particles (more than 60\%), as well as compounds of silicon, aluminum, iron, calcium and magnesium (see in Table 1). This is consistent with data provided in published sources [18]. The composition of the coal portion of the solid residue is almost identical to the composition of the coal burned that determines its properties [11].

It is known that coal is a porous material penetrated by a system of pores and fissures with dimensions of $10^{-8}$ to $10^{-10}$ $\mathrm{m}$. The presence of a developed system of micro- and macropores in the coals determines a specific surface area of up to $200 \mathrm{~m}^{2} / \mathrm{g}$, which contributes to their high hydration capacity $[1,14,20,21]$. According to studies using the BET method, the specific surface area of the selected samples was more than $8.0 \mathrm{~m}^{2} / \mathrm{g}$. This is due to the presence of polar functional groups (acid sorption centers) on the surface of coal particles [13]. The interaction of sorption centers with water molecules due to hydrogen and Van der Waals bonds leads to 
the formation of strongly retained adsorption water on the surface of coal particles (Fig. 4) [7].

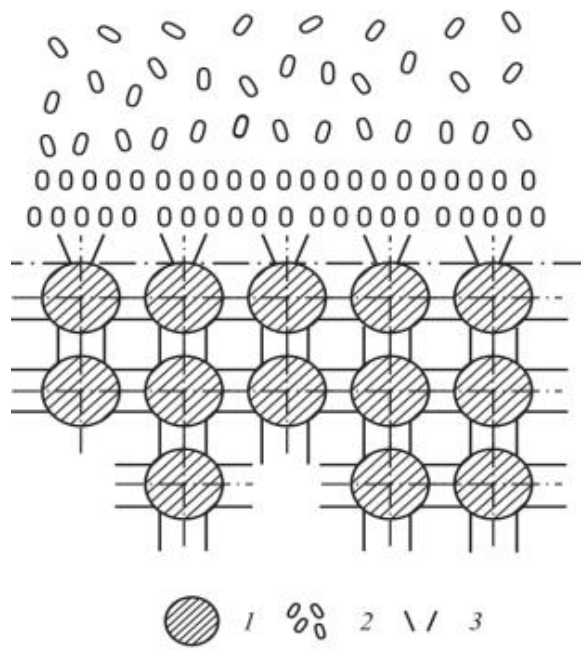

Fig. 4. Formation of adsorption water on the surface of coal particles [3]: 1 - molecules of coal particles; 2 - water molecules; 3 - polar functional groups

It follows that the formation of a hydration shell, the thickness of which can reach $(0.3 \div 4.0) \cdot 10^{-9} \mathrm{~m}$, leads to a decrease in the pore space and is accompanied by a process of slowing down the filtration of free water or its absence under conditions of low hydraulic gradient. The consequence of this is the low water permeability of the studied ash and slag and the presence of an initial gradient of filtration, which should be the subject of a separate study.

According to current recommendations on the use of the ash and slag waste as additional layers of the road pavement, the studied samples must satisfy the requirements presented in Table 4.

Table 4. Recommended requirements for the permeability of the ash and slag when using them as additional layers of the road pavement [15]

\begin{tabular}{cc}
\hline Possible area of use & $\begin{array}{c}\text { Coefficient of water } \\
\text { permeability } \boldsymbol{k}, \mathbf{m} / \mathbf{d a y}\end{array}$ \\
\hline $\begin{array}{c}\text { Drainage, frost-protective, heat- } \\
\text { insulating layer }\end{array}$ & $\geq 1.0$ \\
\hline $\begin{array}{c}\text { Frost-protective and heat-insulating } \\
\text { layer }\end{array}$ & $\geq 0.2$ \\
\hline
\end{tabular}

Frost-protective and heat-insulating

layers of pavement with the use of technical reclamation

less than 0.2

(strengthening with binders, waterproofing, etc.)

Note: In addition, the criteria for the applicability of ash and slag are the weight loss during calcination and the amount of frost heaving

According to the above permeability guidelines, the ash and slag wastes of both ash dumps can be used as additional layers of the road pavement. However, their application can be limited due to the existing hydraulic gradient, which may be lower than the initial one, that will lead to the formation of a stagnant filtration mode and excludes the use of the ash and slag as a drainage layer.

\section{CONCLUSIONS}

Laboratory studies of the water permeability of the lowcalcium, highly-acid ash and slag under the steady flow conditions allowed us to draw the following conclusions.

The value of permeability coefficient of the studied samples, despite the gravel and coarse-grained composition, varies from $1.0 \div 1.1 \mathrm{~m} /$ day to $1.1 \div 1.2 \mathrm{~m} /$ day (at $10{ }^{\circ} \mathrm{C}$ ) in dense and loose state, respectively.

For the studied ash and slag, the presence of an initial hydraulic gradient varying in the range of 0.49 to 0.53 was found.

The low values of the permeability coefficients, as well as the presence of initial hydraulic gradient, are explained by the chemical composition of the ash and slag containing a large amount of unburned coal particles. Their presence increases the sorption activity of deposits (the specific surface area is $8.0 \mathrm{~m}^{2} / \mathrm{g}$ ), accompanied by the formation of hydration shells on the surface of coal particles and the deceleration of free water filtration.

In accordance with current recommendations on the permeability, the studied ash and slag wastes can be used as additional layers of pavement. In this case, special attention should be paid to the current hydraulic gradient, the small values of which can limit the area of their use.

\section{REFERENCES}

[1] Adibee, N., Osanloo, M., Rahmanpour, M. Adverse effects of coal mine waste dumps on the environment and their management. Environmental Earth Sciences, 2013, 70 (4), pp. 1581-1592. DOI: 10.1007/s12665013-2243-0.

[2] Avgushevich, I.V., Sidoruk, E.I. Bronovets, T.M. Standard Coal Testing Methods. Advertising Master Publishing, Moscow, 2018, 576 p.

[3] Avdokhin, V.M. Coal Beneficiation: Textbook for Universities: Processes and Machines, Vol. 1. Publishing House "Mining Book", Moscow, 2012, $424 \mathrm{p}$.

[4] Afinogenov, O.P., Malykhin, R.N. The Use of Ash and Slag Waste from the Kuzbass Thermal Power Plants (TPP) for the Construction of the Road Pavements. Technique. Technology. Engineering, Vol. 2, 2019, pp. 20-24.

[5] Boikov, A.V., Ivanov, P.V. Application of carbonaceous household wastes as fuel feedstock at thermo metallurgical equipment and processes. Journal of Ecological Engineering, 17 (3), pp. 18-21. DOI: $10.12911 / 22998993 / 63474$. 
[6] Dolzhikov, V.V., Marinin, M.A. Quality preparation improvement of mined rock for mining extraction considering spatial temporary formation of field strain. IOP Conference Series: Earth and Environmental Science, 87 (5), 2017. DOI: 10.1088/17551315/87/5/052003.

[7] Glushenko, I.M. Theoretical Fundamentals of the Technology of Fossil Fuels: Textbook for Universities. Metallurgy, Moscow, 1990, 296 p.

[8] Goldberg, V.M., Gazda, S. Fundamentals of Hydrogeology for the Protection of Groundwater from Pollution. Nedra, Moscow, 1984, 262 p.

[9] GOST 25584-2016 Soils. Laboratory Methods for Determination of Coefficient of Hydraulic Conductivity. Standartinform, Moscow, 2016, 19 p.

[10] Iakovleva E. V., Belova M. V., Popov A. L. Mining and Environmental Monitoring at Open-Pit Mineral Deposits. Journal of Ecological Engineering, 20 (5), 2019, pp. 172-178.

[11] Kizilstein, L.Ya., Dubov, N.V., Spitsgluz, A.L., Parade, S.G. Components of Ashes and Slags of Thermal Power Plants (TPP). Energoatomizdat, Moscow, 1995, 176 p.

[12] Komonov, S.V., Ozersky, D.A. The Effect of the Colmatation of the Base and Excavation of Ash and Slag on the Filtration through the Ash Dump of NGRES. Materials of the All-Russian Conference on Groundwater of the East of Russia. Publishing House of ISTU, Irkutsk, 2003, pp. 203-205.

[13] Kotelnikova, T.A., Kuznetsov, B.V., Moreva, A.A., Muravyova, G.A. Sorption Properties of Activated Carbon Modified with Silver Microparticles, According to Nonlinear Gas Chromatography. Sorption and Chromatographic Processes, Vol. 12 (2), 2012, pp. 295-303.

[14] Li, M., Zhang, J., Li, A., Zhou, N. Reutilisation of coal gangue and fly ash as underground backfill materials for surface subsidence control. Journal of Cleaner Production, 254, 2020, paper № 120113. DOI: 10.1016/j.jclepro.2020.120113.

[15] OMD 218.2.031-2013 Guidelines for the Use of Fly Ash and Ash and Slag Mixtures from Coal Combustion at Thermal Power Plants in Road Construction. Moscow, 2014, $60 \mathrm{p}$.

[16] Pasetto, M., Baldo, N. Cold recycling with bitumen emulsion of marginal aggregates for road pavements. Lecture Notes in Civil Engineering, 48, 2020, pp. 155163. DOI: 10.1007/978-3-030-29779-4_15.

[17] Pashkevich, N.V., Tarabarinova, T.A., Golovina, E.I. Problems of reflecting information on subsoil assets in International Financial Reporting Standards. Academy of Strategic Management Journal, 17 (3), pp. 1-9.

[18] Sokol, E.V., Maksimova, N.V., Nigmatulin, E.N., Frenkel, A.E.. Nature, Chemical and Phase Composition of the Energetic Ashes of Chelyabinsk
Coals. Publishing House of the SB RAS, Geo branch, Novosibirsk, 2001, 107 p.

[19] Trushko, O.V., Potemkin, D.A., Popov, M.G. Ensuring sustainability of mining workings in development of ore deposits in complex geological conditions. ARPN Journal of Engineering and Applied Sciences, 13 (7), 2019, pp. 2594-2601.

[20] Wang, D., Tawk, M., Indraratna, B., Heitor, A., Rujikiatkamjorn, C. A mixture of coal wash and fly ash as a pavement substructure material. Transportation Geotechnics, 21, 2019, paper № 100265. DOI: 10.1016/j.trgeo.2019.100265.

[21] Zhou, X., Shen, J. Micromorphology and microstructure of coal fly ash and furnace bottom slag based light-weight geopolymer. Construction and Building Materials, 242, 2020, paper № 118168. DOI: 10.1016/j.conbuildmat.2020.118168. 